\title{
Odontogenic differentiation potential of human dental pulp cells cultured on a calcium-aluminate enriched chitosan-collagen scaffold
}

\author{
Diana Gabriela Soares ${ }^{1} \cdot$ Hebert Luís Rosseto ${ }^{2}$. Débora Salles Scheffel ${ }^{3}$. \\ Fernanda Gonçalves Basso ${ }^{1}$. Claudia Huck ${ }^{4}$. Josimeri Hebling ${ }^{3}$. \\ Carlos Alberto de Souza Costa ${ }^{1}$
}

Received: 16 May 2016 / Accepted: 20 February 2017 /Published online: 9 March 2017

(C) Springer-Verlag Berlin Heidelberg 2017

\begin{abstract}
Objective The study aims to evaluate the odontogenic potential of human dental pulp cells (HDPCs) in contact with an experimental porous chitosan-collagen scaffold (CHC) enriched or not with a mineral phase of calcium-aluminate (CHC-CA).

Material and methods To assess the chemotactic effect of the materials, we placed HDPCs seeded on transwell membranes in intimate contact with the $\mathrm{CHC}$ or CHC-CA surface, and the cell migration was monitored for $48 \mathrm{~h}$. Additionally, cells were seeded onto the material surface, and the viability and proliferation were evaluated at several time points. To assess the odontoblastic differentiation, we evaluated ALP activity, DSPP/DMP-1 gene expression, and mineralized matrix deposition. HDPCs cultured onto a polystyrene surface (monolayer) were used as negative control group.

Results The experimental CHC-CA scaffold induced intense migration of HDPCs through transwell membranes, with cells attaching to and spreading on the material surface after 24-h incubation. Also, the HDPCs seeded onto the CHC-CA scaffold were capable of migrating inside it, remaining viable and
\end{abstract}

\footnotetext{
Carlos Alberto de Souza Costa

casouzac@foar.unesp.br

Diana Gabriela Soares

diana_odonto@yahoo.com.br

Hebert Luís Rosseto

hlrossetto@gmail.com

Débora Salles Scheffel

de_salles@yahoo.com.br

Fernanda Gonçalves Basso

fergbasso@gmail.com

Claudia Huck

claudia.huck@hotmail.com
}

featuring a proliferative rate more rapid than that of $\mathrm{CHC}$ and control groups at 7 and 14 days of cell culture. At long-term culture, cells in the CHC-CA scaffold featured the highest deposition of mineralized matrix and expression of odontoblastic markers (ALP activity and DSPP/DMP-1 gene expression).

Conclusions According to the results, the CHC-CA scaffold is a bioactive and cytocompatible material capable of increasing the odontogenic potential of human pulp cells. Based on analysis of the positive data obtained in this study, one can suggest that the CHC-CA scaffold is an interesting future candidate for the treatment of exposed pulps.

Clinical relevance The experimental scaffold composed by a chitosan-collagen matrix mineralized with calcium aluminate seems to be an interesting candidate for in vivo application as a cell-free approach to dentin tissue engineering, which may open a new perspective for the treatment of exposed pulp tissue.

Keywords Tissue engineering $\cdot$ Stem cells $\cdot$ Extracellular matrix $\cdot$ Regenerative medicine $\cdot$ Endodontics

\author{
Josimeri Hebling \\ jhebling@foar.unesp.br
}

1 Department of Physiology and Pathology, Araraquara School of Dentistry, University Estadual Paulista - UNESP, Humaitá Street, 1680, Araraquara, SP 14801-903, Brazil

2 Ribeirão Preto School of Medicine, São Paulo University - USP, Avenida do Café, Ribeirão Preto, SP 14040-903, Brazil

3 Department of Orthodontics and Pediatric Dentistry, Araraquara School of Dentistry, University Estadual Paulista - UNESP, Humaitá Street, 1680, Araraquara, SP 14801-903, Brazil

4 Department of Operative Dentistry, Araraquara School of Dentistry, University Estadual Paulista - UNESP, Humaitá Street, 1680, Araraquara, SP 14801-903, Brazil 


\section{Introduction}

Maintenance of pulp vitality is essential for physiologic tooth functions, including sensory and immune reactions, nourishment, and formation of dentin as active defense mechanisms $[1,2]$. The rigid chamber of dentin surrounds the pulp tissue, providing strong mechanical support and protection. When dentin loses its integrity, leading to pulp exposure, vital pulp therapy requires the regulation of tertiary dentinogenesis, a tissue-specific process, to reconstitute normal tissue continuum at the pulp-dentin border [3]. Strategies to promote repair and regeneration of the pulp-dentin complex are now emerging based on the interaction of natural or synthetic scaffolds with cells and signaling molecules, guiding the natural woundhealing events [4-6]. Regenerative medicine has been demonstrated to have the potential for improved treatment outcomes by means of stem cell-based therapies [6, 7]. Regarding dentin regeneration, a cell-free approach seems to be a rational alternative, as pulp tissue has several stem cell niches at the quiescent stage [2]. Under a proper stimulus, these cells exit the niche, migrate, proliferate, and differentiate to regenerate the damaged tissue [8]. For such purposes, the development of porous and bioactive scaffolds that mimic the natural dentin extracellular microenvironment is critical $[9,10]$.

Mineral-containing chitosan-collagen scaffolds have been extensively studied for mineralized tissue regeneration due to their similarity to bone/dentin extracellular matrix (ECM), controlled degradation rate, and mechanical strength [11-19]. Recently, a chitosan-collagen two-dimensional (2D) biomembrane embedded with calcium-aluminate (CA) was developed for such purposes. This biomaterial featured intense bioactive potential with dental pulp cells, leading to increased expression of odontoblastic marker phenotype, along with expressive deposition of mineralized matrix in vitro [20]. The similarity with glycosaminoglycan, the good biocompatibility with pulp cells [21-23], and antimicrobial activity [24, 25] of chitosan are interesting features for dentin regeneration. Calciumaluminate (CA) is biocompatible, with a bioactive mineral phase that provides the $\mathrm{Ca}^{2+}$ gradient and a slightly alkaline pH (7.6-8.9) environment [26, 27], which has been shown to induce cell migration and differentiation $[28,29]$. Therefore, the association of chitosan matrix and CA may be considered as promising alternative for mineralized tissue regeneration.

According to Gupte and Ma [10], to achieve successful regeneration in tissue engineering field, an approach involving a tri-dimensional (3D) porous matrix seems to be more suitable, since it creates a designed microenvironment for cell support and growing. The porous network of 3D scaffold allows for cell migration inside its structure, followed by cell proliferation and differentiation, and ultimately with new tissue deposition, restoring tissue function. In view of this, in the present investigation, a porous chitosan-collagen calcium-aluminate (CHC-CA) scaffold was developed regarding its potential for dentin regeneration. The chemotactic potential, cytocompatibility, and bioactivity of this experimental CHC-CA scaffold were tested on human dental pulp cells, in order to evaluate its potential for a cell-free approach in dentin tissue engineering.

\section{Materials and methods}

\section{Scaffold preparation and characterization}

First, a collagen gel suspension from bovine tendon was obtained. The collagen was extracted in $0.9 \% \mathrm{w} / v$ sodium chloride (Sigma-Aldrich, St. Louis, MO, USA) followed by treatment with $1.42 \mathrm{M}$ sodium $\left(\mathrm{Na}^{+}\right), 0.37 \mathrm{M}$ potassium $\left(\mathrm{K}^{+}\right)$, $0.54 \mathrm{M} \mathrm{Ca}^{++}$, and $6 \% \mathrm{w} / v$ dimethyl sulfoxide solution (Sigma-Aldrich). The collagen gel was then filtered, treated with a salt-rich solution $\left(1.42 \mathrm{M} \mathrm{Na}^{+}, 0.37 \mathrm{M} \mathrm{K}^{+}\right.$, and $0.54 \mathrm{M}$ $\mathrm{Ca}^{++}$), filtered one more time, and neutralized with $3 \% \mathrm{w} / \mathrm{v}$ boric acid solution (Sigma-Aldrich). Excess salts were removed after successive rinses with deionized water, and the solid was suspended in acetic acid $(0.55 \mathrm{~mol} / \mathrm{L}, \mathrm{pH} 3.5$; Sigma-Aldrich). The collagen concentration was determined by lyophilization, at around $0.9-1.3 \% w / v$. The collagen gel was mixed with a chitosan solution (75-85\% deacetylated, animal origin; Sigma-Aldrich), previously prepared (1 g chitosan dissolved in $50 \mathrm{~mL}$ of acetic acid $2 \% w / v$; SigmaAldrich), at a 2:1 v/v rate, followed or not by addition of the calcium-aluminate cement. Then, the materials were frozen $\left(-80^{\circ} \mathrm{C}\right)$ and lyophilized, to remove the water by sublimation, and then dried at a specific temperature to promote crosslinking between the collagen fibrils and the calcium-aluminate. The calcium-aluminate matrix was composed of $65 \%$ $\mathrm{CaO} \cdot \mathrm{Al}_{2} \mathrm{O}_{3}, 25 \% \mathrm{CaO} \cdot 2 \mathrm{Al}_{2} \mathrm{O}_{3}$, and $10 \% 12 \mathrm{CaO} \cdot 7 \mathrm{Al}_{2} \mathrm{O}_{3}$.

Therefore, two scaffolds were formulated: (1) $\mathrm{CHC}$ scaffold - chitosan-collagen scaffold with no addition of mineral phase and (2) CHC-CA scaffold-chitosan-collagen scaffold containing the mineral phase of calcium aluminate. Cylindrical samples of each scaffold measuring $5 \mathrm{~mm}$ diameter and $1 \mathrm{~mm}$ thickness were obtained, featuring thus a $55-\mathrm{mm}^{2}$ tri-dimensional (3D) area for cell growing. A polystyrene (PS) disc measuring $8 \mathrm{~mm}$ diameter was used as negative control, which allowed a $50-\mathrm{mm}^{2}$ surface area for two-dimensional (2D) cell growing (monolayer). Prior to being used in in vitro tests, the materials were sterilized by gamma radiation (CBE, Cotia, São Paulo, Brazil) with the irradiation dose fixed at $20 \mathrm{KGy}$. The superficial morphology as well as the presence of calciumaluminate in the scaffold was detected by scanning electron microscopy (SEM; $10.0 \mathrm{kv}$ ) and by energy-dispersive Xray spectroscopy (EDS; $25 \mathrm{kv}$; take-off angle 3.7) (JEOLJMS-6610V Scanning Microscope, Tokyo, Japan). The sizes of mineral particles were measured with ImageJ software (National Institutes of Health, Bethesda, MD, USA). 


\section{Primary culture of human dental pulp cells (HDPCs)}

The pulp tissue from three sound human third molars from a young patient (24 years old) was collected (Proc. No. 30939314.5.0000.5416; approved by the Research Ethics Committee of the Araraquara Dental School/UNESP, São Paulo, Brazil) and subjected to enzymatic digestion in collagenase, as previously described [30]. Cell suspension was plated in 6-well culture plates in complete Dulbecco's modified Eagle medium (DMEM; Gibco, Grand Island, NY, USA) supplemented with $100 \mathrm{IU} / \mathrm{mL}$ penicillin, $100 \mu \mathrm{g} / \mathrm{mL}$ streptomycin, $2 \mathrm{mmol} / \mathrm{L}$ glutamine, and $10 \%$ fetal bovine serum (FBS; Gibco). The cells were allowed to attach to the plate for $3 \mathrm{~h}$, when the non-adherent cells were removed and remained cells were cultured with fresh DMEM. This procedure was performed to straightforward isolation and culture of mesenchymal stem cells (MSCs) from pulp tissue, in the same way as performed for MSC isolation from bone marrow [31]. After reaching 80-90\% confluence, the culture was expanded and cells in the third passage were seeded on 24-well plates ( $80 \%$ confluence) and subjected to immunofluorescence assay for the stem cell markers STRO-1 and CD-146 [32]. Briefly, the cells were fixed in $4 \%$ buffered paraformaldehyde, then permeabilized with $0.1 \%$ Triton (Sigma Chemical Co.), and blocked in 5\% BSA (Santa Cruz Biotechnology, Santa Cruz, CA, USA). Next, the cells were incubated with the primary antibodies (1:50; Santa Cruz Biotechnology) at $4{ }^{\circ} \mathrm{C}$ for $12 \mathrm{~h}$, followed by incubation for $1 \mathrm{~h}$ with secondary antibody conjugated with FITC (fluorescein isothiocyanate. 1:1000; Santa Cruz Biotechnology) at room temperature. After this, the cells were incubated with Hoechst (1:5000; Invitrogen San Francisco, CA, USA) for nuclear contra-fluorescence. The cells were analyzed in the IN Cell Analyser 2000 (GE Healthcare Life Sciences, Freiburg, Germany), with 12 images being obtained per compartment $(n=3)$, and the percentage of positively marked cells was obtained by means of the IN Cell Investigation software program (GE Healthcare Life Sciences). Positive marking was observed in 55.9\% for CD146 and $62.7 \%$ for STRO-1. The positive staining for both markers along with the secondary antibodies negative control images are demonstrated in Fig. 1, which indicates the presence of stem cells in the HDPC culture. Therefore, the cell culture used in this present investigation represents a mixed culture of pulp cells, containing a sub-population of stem cells. Cells at passage no. 3 were used in this experiment.

\section{Induction of cell migration}

To assess the capability of the CHC-CA scaffold to induce HDPC migration to its surface, we used transwellpermeable supports $(8.0 \mu \mathrm{m}$ pore size; polycarbonate membrane; Corning Inc., Corning, NY, USA). The transwells were incubated in complete DMEM at $37{ }^{\circ} \mathrm{C}$ and $5 \% \mathrm{CO}_{2}$ for $1 \mathrm{~h}$. Then, $1 \times 10^{4}$ cells were seeded onto the upper membrane surface, followed by incubation at $37{ }^{\circ} \mathrm{C}$ and $5 \% \mathrm{CO}_{2}$ for $2 \mathrm{~h}$ to allow for initial cell attachment. After that, the transwell was transferred to 24-well plates containing the CHC-CA or CHC scaffolds $(5 \mathrm{~mm}$ diameter and $1 \mathrm{~mm}$ thickness) in DMEM with no FBS, such that the material surface was in direct contact with the lower surface of the transwell membrane. In the control group, the transwell was incubated in DMEM with no FBS. The samples were incubated for 24 and $48 \mathrm{~h}$ at $37{ }^{\circ} \mathrm{C}$ and $5 \% \mathrm{CO}_{2}$. Then, the membranes $(n=4)$ were stained with crystal violet and analyzed by light microscopy (Olympus BX51). Images of four fields from each membrane (upper surface) were taken with a digital camera (Olympus C5060, Miami, FL, USA), and the number of cells was determined with ImageJ software (National Institutes of Health). The mean value for each sample was used for statistical analysis. Scanning electron microscopy (JEOL-JMS-6610V Scanning Microscope) was performed on the upper and lower membrane surfaces of the transwells and also on the scaffolds surface at each period of analysis $(n=2)$, as previously described [33].

\section{Analysis of cytocompatibility}

The PS disc and the scaffolds (CHC and CHC-CA) were positioned in a metallic device between two silicon rings, and this set was placed into 24-well plates, in such a way that the materials were kept $6.0 \mathrm{~mm}$ distant from the culture plate surface, to prevent cell migration (Fig. 2). In total, $3 \times 10^{4}$ cells were seeded on the material surface, and the construct was incubated at $37^{\circ} \mathrm{C}$ and $5 \% \mathrm{CO}_{2}$ for $30 \mathrm{~min}$ to allow for initial cell adhesion. Then, the HDPCs were cultivated in complete DMEM (medium was changed every $48 \mathrm{~h}$ ). Cell proliferation, viability, and morphology were assessed after 1-, 7-, 14-, 21-, and 28-day incubation.

\section{Cell viability}

The cell viability analysis was performed by use of the Live/Dead® Viability/Cytotoxicity Kit (Invitrogen, San Francisco, CA, USA). At each time point $(n=4)$, the samples were washed once in phosphate-buffered saline (PBS) and incubated for $45 \mathrm{~min}$ with PBS supplemented with $4 \mu \mathrm{M}$ ethyl homodimer-1 (Eth-1) and $2 \mu \mathrm{M}$ Calcein AM (CA). The materials were then analyzed by fluorescence microscopy (Leica DM 5500B, Nussloch GmbH, Nussloch, Germany). Images of four fields were obtained from each material surface, and the percentage of live cells at each time point was calculated (ImageJ software). We evaluated 0.5-mm-thick transverse slices of the scaffolds to observe the presence of viable cells inside the material. 

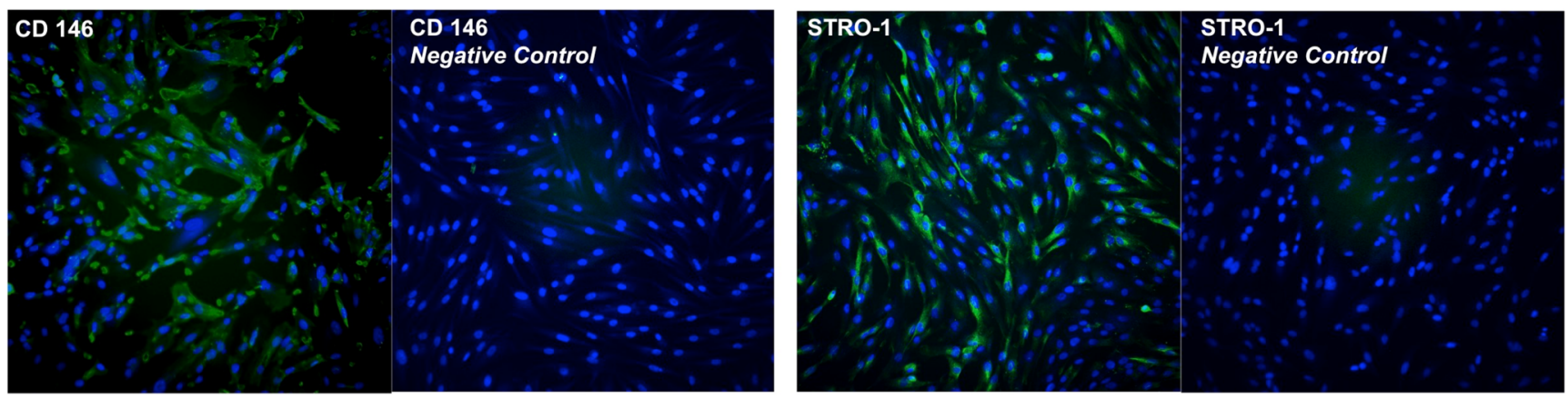

Fig. 1 Immunofluorescence images for the stem cell markers STRO-1 and CD-146 and respective secondary antibody controls $(\times 20)$. Green fluorescence (FITC) indicates positively stained cells for the markers. Blue fluorescence demonstrates the nuclei (Hoescht)

\section{Cell proliferation}

The cell metabolic activity was monitored by means of the Alamar Blue ${ }^{\circledR}$ assay (Invitrogen) $(n=6)$. At each time point, the culture medium was aspirated, and the cells were incubated at $37{ }^{\circ} \mathrm{C}$ and $5 \% \mathrm{CO}_{2}$ for $4 \mathrm{~h}$ with $2 \mathrm{~mL}$ of Alamar Blue ${ }^{\circledR}$ dye diluted in DMEM with no FBS (1:10). Then, the fluorescence was read at $570 \mathrm{~nm}$ excitation and $585 \mathrm{~nm}$ emission (Synergy H1, BioTek, Winooski, VT, USA).

\section{Cell morphology}

At the 28-day time point, two samples were prepared for cell morphology analysis by SEM. Cell morphology was examined at the surfaces of the PS discs and the scaffolds, and in 0.5-mm-thick transverse slices from the scaffolds. EDS analysis was performed to characterize the components of the scaffolds in direct relationship with cells.

\section{Analysis of cell differentiation}

For this assay, the cell/material constructs adapted to the metallic device were cultivated in osteogenic medium (DMEM plus $10 \% \mathrm{SFB}$, supplemented with $10 \mathrm{nmol} / \mathrm{L} \beta$ glycerophosphate and $50 \mu \mathrm{g} / \mathrm{mL}$ sodium ascorbate; Sigma-
Aldrich). Total protein (TP) content and alkaline phosphatase (ALP) activity were measured at 14 days, and the gene expression of odontoblastic markers and mineralized matrix deposition were assessed at 28 days.

\section{TP quantification/ALP activity}

Cell lysis was performed in $0.1 \%$ sodium lauryl sulfate (Sigma-Aldrich Corp.) solution. The scaffolds were subjected to mechanical disruption, and the supernatant was collected after centrifugation (4000 rpm/10 min). ALP activity measurement was performed with a thymolphthalein monophosphate substrate kit (Labtest Diagnóstico S.A., Lagoa Santa, MG, Brazil), and TP dosage was performed according to the Read \& Northcote protocol [30]. The concentrations of ALP and TP production were calculated with a standard curve; then, the ALP activity was normalized by TP content. The percentages of ALP activity relative to the PS group (negative control) were calculated $(n=6)$.

\section{Real-time PCR}

Total RNA was extracted with the RNAqueous ${ }^{\circledR}$-micro kit (Ambion, Austin, TX, USA), and cDNA was reversetranscribed with the High Capacity cDNA Reverse
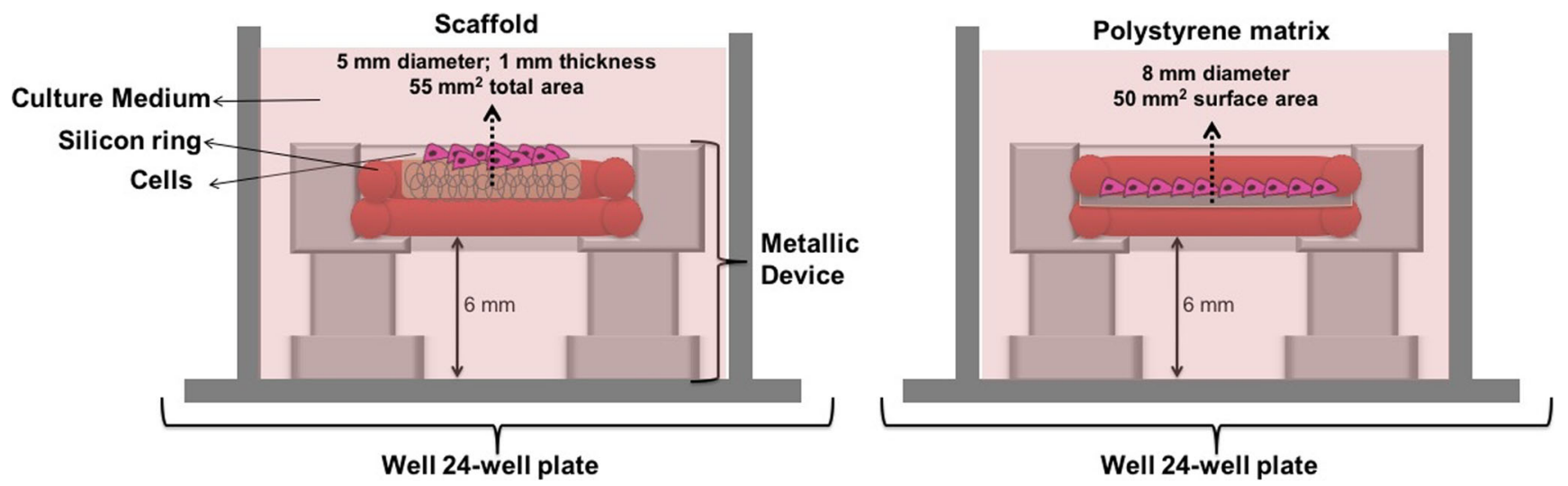

Fig. 2 Schematic representation of experimental protocol for cell seeding on materials surface by using the metallic device, taking in account the cell growing area for each substrate 
Transcription Kit (Applied Biosystems, Foster City, CA, USA), according to the recommended protocol. Real-time PCR quantification of mRNA $(n=6)$ was performed in StepOne Plus equipment (Applied Biosystems) by the use of Taqman assays: DMP-1-Hs01009391_g1, DSPPHs00171962 m1. The CT value of DSPP and DMP-1 was normalized by the constitutive gene and $\beta$-actin (Hs01060665_g1). The data of gene expression were normalized by those obtained on PS group (negative control).

\section{Alizarin red assay}

The cell/material constructs $(n=6)$ were fixed in $70 \%$ ethanol at $4{ }^{\circ} \mathrm{C}$, washed in distilled water, and then stained with Alizarin red dye (40 mM, pH 4.2; Sigma-Aldrich). Scaffolds (CHC and CHC-CA) with no cells $(n=6)$ were used to eliminate the background. The materials were washed in deionized water and incubated with $10 \%$ cetylpyridinium chloride (Sigma-Aldrich), and the absorbance of the leached solution was measured at $570 \mathrm{~nm}$ (Synergy H1). The PS group mean absorbance was considered as $100 \%$ of Alizarin red staining.

\section{$X$-ray microtomography $(\mu C T)$ analysis}

The percentage of mineralized matrix before and after 28 days of cell culture in the scaffolds was also detected by $\mu \mathrm{CT}$. The samples were scanned in SkyScan Micro-CT (1176, Bruker, Kontich, Belgium) to obtain 3D models, and the mineralized volume was obtained by means of SkyScan CT analyser and CT volume software (Bruker). Three regions of $50 \mu \mathrm{m}$ were scanned in each sample $(n=4)$, and the average value was used for statistical analysis.

\section{Statistical analysis}

The experiments were performed twice to ensure reproducibility. Data were analyzed by two-way ANOVA complemented by Tukey's test for observation of the significance differences between the study groups. A value of $p<0.05$ was considered to be statistically significant.

\section{Results}

\section{Scaffold characterization}

Both scaffolds featured a porous 3D matrix, as observed by low magnification $(\times 100)$ SEM images at the surface and in transversal slices of the materials (Fig. 3). High magnification images demonstrated the presence of an organic matrix interlaced with mineral components on CHC-CA scaffold, whereas the CHC scaffold featured a smooth surface. The EDS analysis of superficial mineral structures demonstrated the presence of calcium $(\mathrm{Ca})$ and aluminum $(\mathrm{Al})$, the main components of the calcium-aluminate phase. This mineral phase was organized in microparticle agglomerates with single microparticles measuring from 0.12 to $0.5 \mu \mathrm{m}$ (average $=$ $0.31 \pm 0.10 \mu \mathrm{m})$ and agglomerates measuring from 0.71 to $4.90 \mu \mathrm{m}$ (average $=1.47 \pm 1.02 \mu \mathrm{m})$. The presence of $\mathrm{Al}$ and $\mathrm{Ca}$ was not detected on the $\mathrm{CHC}$ scaffold.

\section{Cell migration}

A significantly lower number of cells was observed on the upside of the transwell membrane for the $\mathrm{CHC}$ and $\mathrm{CHC}$ CA groups in comparison with that on the PS group at both time points $(p<0.05)$. The CHC-CA presented significantly lower cells than CHC group $(p<0.05)$. The SEM images demonstrated a reduced number of cells on the upside of the transwell membrane for the CHC-CA group when compared with $\mathrm{CHC}$ and PS groups. The presence of migrating cells located on the scaffold surface was observed only for the CHC-CA group (Fig. 4).

\section{Cell viability, proliferation, and morphology}

No significant difference for the percentage of viable cells at each time point among the groups was observed $(p>0.05)$ (Fig. 5a). For cell proliferation assay (Fig. 5b), significant increase in the percentage of cell metabolism throughout time points was observed for all experimental groups $(p<0.05)$. For the CHC-CA group, significantly increased cell metabolism was observed at the 7- and 14-day time points relative to $\mathrm{CHC}$ and PS groups, whereas the $\mathrm{CHC}$ group featured significantly higher cell metabolism compared with PS group only at 7 days of cell culture $(p<0.05)$. Nevertheless, at the $21-$ and 28-day time points, no significant difference among groups was observed $(p>0.05)$. Representative images of live/dead analysis at 1, 14, and 28 days are shown in Fig. 5c-e. It was observed that cells were capable of attaching to and spreading on the scaffolds surface as well as migrating inside the biomaterials, where they maintained their viability (live/dead images). The SEM evaluation (Fig. 6) showed that the cells were capable to adhere and spread onto the surface of all materials. Cells inside the $\mathrm{CHC}$ and CHC-CA scaffolds at the 28-day period were observed.

\section{Differentiation marker expression}

Considering the PS group as $100 \%$ of ALP activity/TP production, significantly increased ALP activity and TP production was observed for the $\mathrm{CHC}-\mathrm{CA}$ relative to $\mathrm{PS}$ and $\mathrm{CHC}$ groups $(p<0.05)$ (Fig. 7a, b). The CHC-CA group also featured the highest mRNA gene expression of DMP-1 and DSPP $(p<0.05)$ (Fig. 7c, d). Regarding mineralized matrix deposition, significantly higher Alizarin red staining was 


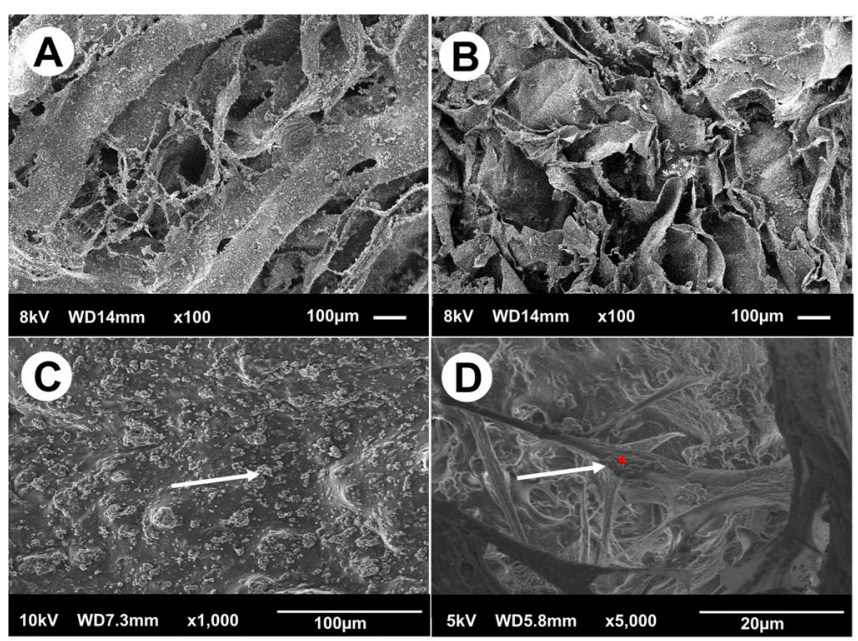

(E)

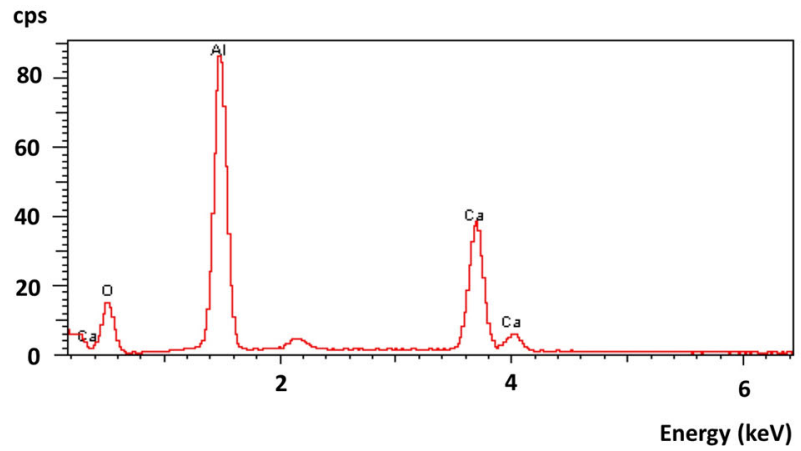

Fig. 3 Scaffold characterization. a, b SEM view of the CHC-CA scaffold surface and transversal slice, respectively, at low magnification $(\times 100)$. c, d SEM view of the CHC-CA scaffold surface and transversal slice, respectively, at high magnification $(\times 1000$ and $\times 5000$, respectively). Note the presence of mineral aggregates on material surface surrounded by the organic matrix (arrows). e EDS analysis of mineral structures

detected on the $\mathrm{CHC}$ and CHC-CA group compared with the PS group $(p<0.05)$, with CHC-CA scaffold featuring the highest amount of mineralized matrix (Fig. 7e). Micro-CT analysis of scaffolds demonstrated an increase in the percentage of mineralized volume 28 days after cell seeding; however, the CHC-CA group exhibited an intense increase on this feature when compared to $\mathrm{CHC}$ group (Fig. 7f).

\section{Discussion}

Currently, the application of tissue engineering concepts for the development of biomaterials capable of driving dental pulp stem cell migration and differentiation has been the focus of regenerative dentistry, mainly for the treatment of pulp exposures [34]. Mineralized tissues are characterized as fibrillar collagenous extracellular matrix infiltrated with non-collagenous proteins and proteoglycans, embedded with calcium-rich minerals [35]. Three-dimensional extracellular matrix scaffolding that mimics

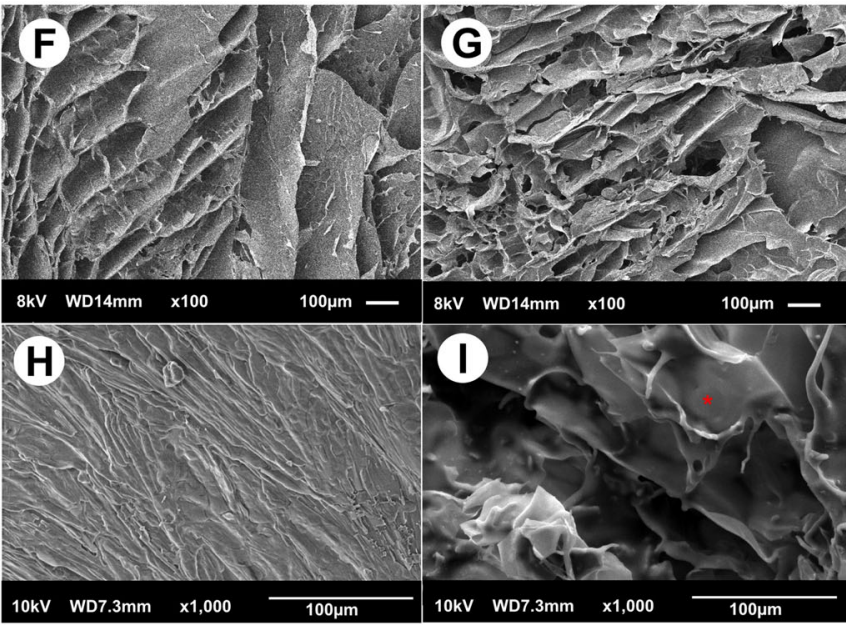

\section{J}

cps

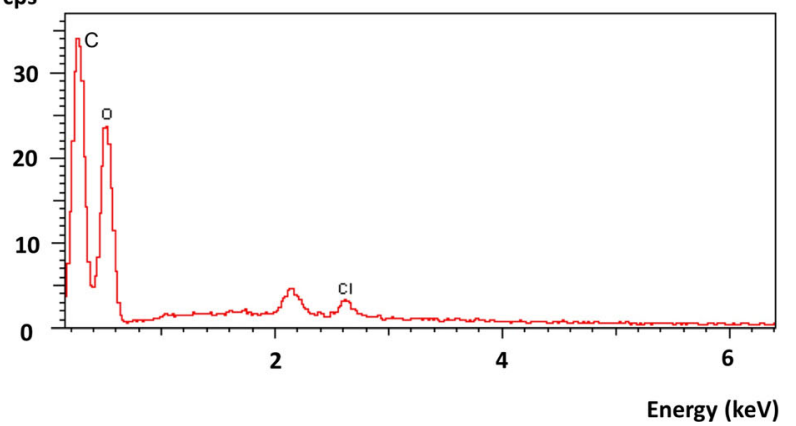

(asterisk) observed on d. f, $\mathbf{g}$ SEM view of the CHC scaffold surface and transversal slice, respectively, at low magnification $(\times 100)$. $\mathbf{h}, \mathbf{i}$ SEM view of the CHC scaffold surface and transversal slice, respectively, at high magnification $(\times 1000)$. $\mathbf{j}$ EDS analysis of $\mathrm{CHC}$ structure (asterisk) observed on $\mathbf{i}$

this natural environment appears to be essential for eliciting differentiation responses from resident cells and creates a molecular environment receptive for mineralization [10]. As collagen type I is the main component of dentin matrix, collagen-based scaffolds have been frequently used to reproduce the process of dentinogenesis [35]. However, collagen is easily degraded in biological media, and its mechanical properties are weak. In view of this, a chitosan-collagen composite has emerged as an interesting alternative, as chemical interaction between $\mathrm{NH}_{3}^{+}$chitosan residues and $\mathrm{COO}-$ collagen groups significantly reduces the degradation rate of collagen [36]. Mineral-rich chitosan-collagen composites have been considered the ideal materials for mineralized tissue regeneration by providing a favorable environment for the infiltration and function of osteogenic/odontogenic cell types, which leads to the enhancement of osteoconductivity, with the advantage of increased material mechanical strength [11-19].

Previously, our group demonstrated that a chitosancollagen 2D matrix embedded with calcium-aluminate mineral phase was cytocompatible with human dental pulp cells and 


\section{B}

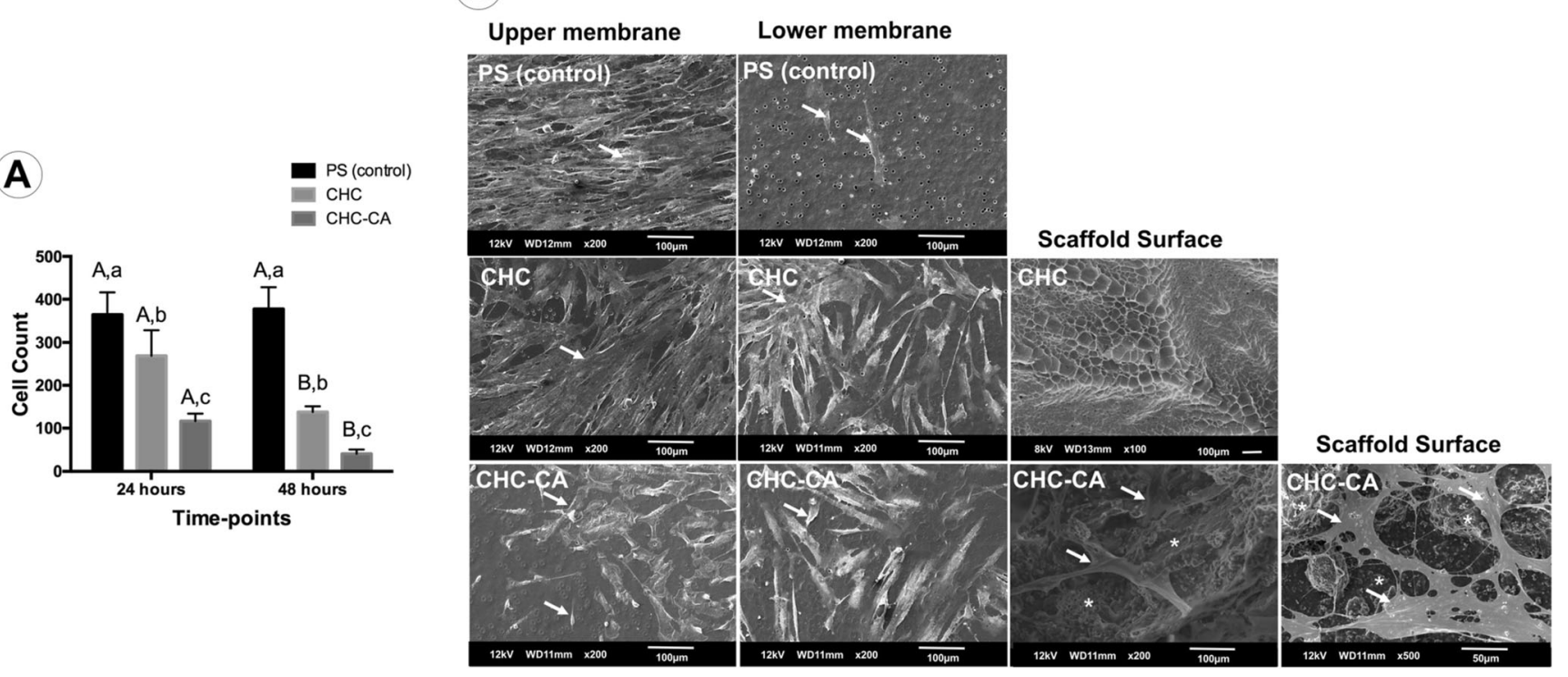

Fig. 4 Active cell migration analysis. a Bar graph for the mean ( \pm standard deviation) numbers of cells at the upper membrane surfaces of transwells on PS (control), CHC, and CHC-CA groups at each time point. Lower-case letters allow comparison between groups at each time point; upper-case letters allow comparison between time points for each group; different letters indicate significant differences (two-way ANOVA; Tukey's test; $p<0.05$ ). b Representative SEM images at the 24-h time point. The PS control group featured several cells on the upper membrane surface, with few cells being observed at the lower membrane surface. A reduced number of cells were observed covering the upper membrane surface on $\mathrm{CHC}$ and $\mathrm{CHC}-\mathrm{CA}$ groups and an increased number of cells were found at the lower membrane surfaces. Cells attached to the CHCCA scaffold surface were observed. Arrows indicate the cells; asterisk indicates the CHC-CA scaffold surface allowed for cell proliferation through time, associated with increased odontoblastic differentiation capability [20]. Therefore, the potential of this formulation to act as a bioactive material for dentin regeneration has been already demonstrated in the literature. In the present investigation, a chitosancollagen calcium-aluminate 3D scaffold was created to mimic the microenvironment of the mineralized organic fiber meshwork of dentin matrix. The capability of this scaffold to induce cell migration to its surface was assessed in order to verify its potential as a cell-free approach, as well as the cell migration and viability inside the porous network. The cell proliferation, odontoblastic differentiation capability, and mineralized matrix deposition were confirmed for this material, and the role of mineral phase in this process was verified.

Both CHC and CHC-CA scaffolds induced migration of HDPCs through the transwell membrane. Odontogenic precursor cell mobilization to sites of tooth repair following injury is the first step required for dentin regeneration in vivo [3]. Also, cells are known to sense and respond to their local environment by using integrin receptor-mediated signaling pathways, particularly to sense the biochemical properties of the ECM proteins, such as collagen, laminin, and fibronectin [37]. Previously, reports also have demonstrated that chitosan possesses a chemotactic potential with pulp cells, since the application of a chitosan membrane on pulp tissue in vivo was capable to induce the migration of mesenchymal stem cells followed by deposition of mineralized matrix [23]. According to our results, the cell migration was more intense for CHCCA scaffold in comparison to CHC scaffold, with cells being capable of attaching to and spreading onto the scaffold surface. The hydration process of the calcium-aluminate matrix leads to formation of calcium-aluminate hydrate $(3 \mathrm{CaO}$. $\left.\mathrm{Al}_{2} \mathrm{O}_{3} \cdot 6 \mathrm{H}_{2} \mathrm{O}\right)$ and aluminum-hydroxide hydrate $\left(\mathrm{Al}_{2} \mathrm{O}_{3} \cdot 3 \mathrm{H}_{2} \mathrm{O}\right)$, followed by slow and gradual release of $\mathrm{Ca}^{2+}$ and $\mathrm{OH}^{-}$after decomposition of the $3 \mathrm{CaO} \cdot \mathrm{Al}_{2} \mathrm{O}_{3} \cdot 6 \mathrm{H}_{2} \mathrm{O}$ phase $[38,39]$. It was previously demonstrated that a $\mathrm{Ca}^{2+}$ gradient has a chemotactic effect on mesenchymal stem cells [40], osteoblasts [41], and fibroblasts [42]. Therefore, both the chitosan/collagen matrix and $\mathrm{Ca}^{2+}$ release in the scaffold may have played a fundamental role in the HDPC migration shown in the present study.

To evaluate the cytocompatibility of the CHC-CA scaffold, we seeded the HDPCs on the surface of this experimental biomaterial and then assessed the proliferation and migration of these cells at several time points. The live/dead assay demonstrated the presence of viable cells at each time point on both $\mathrm{CHC}$ and $\mathrm{CHC}-\mathrm{CA}$ scaffolds. The presence of viable cells was also observed inside the materials at all periods of analysis. Cells seeded on the CHC-CA scaffold showed proliferative rates more rapid than those on the $\mathrm{CHC}$ scaffold and control group (PS) at 7 and 14 days. Analysis of these data attests to the compatibility of the CHC-CA scaffold with HDPCs, such as previously demonstrated for the 2D formulation [20], which is considered a basic pre-requisite for vital 


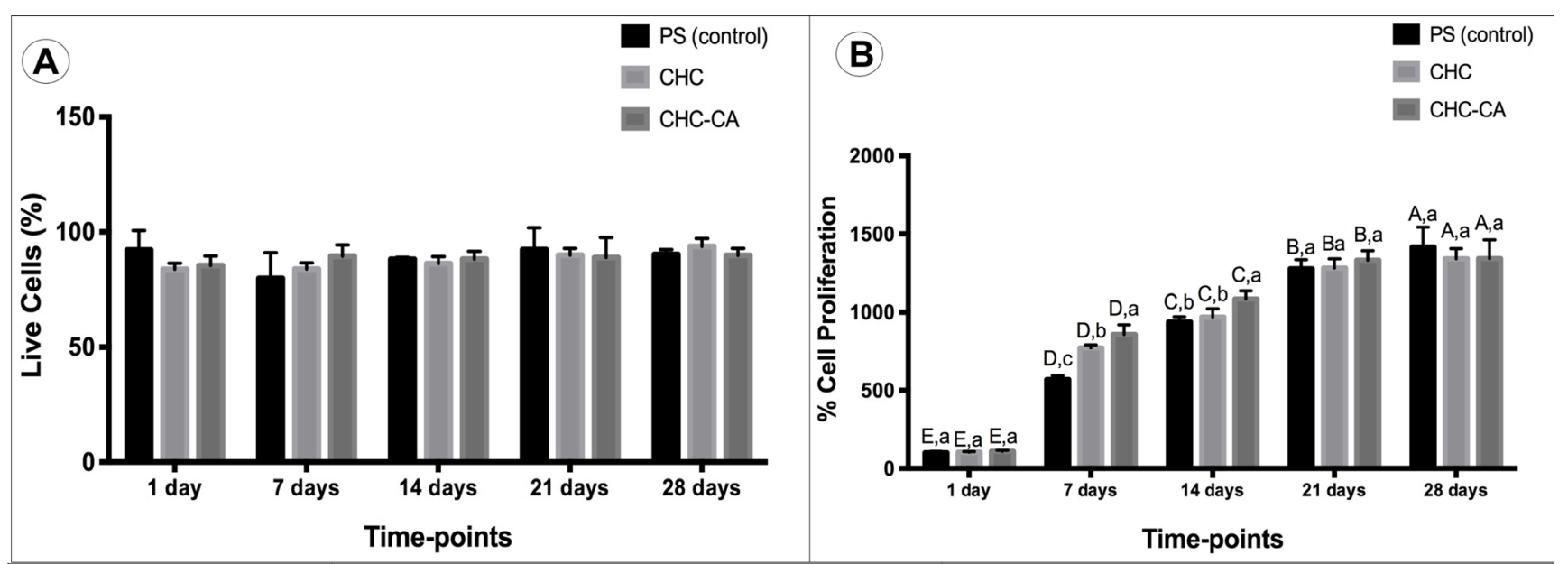

(D)
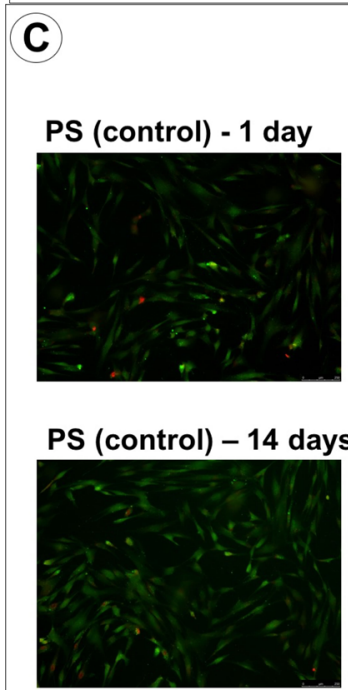

\section{CHC - 1 day Surface}

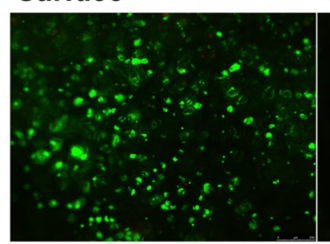

$\mathrm{CHC}-1$ day Transversal

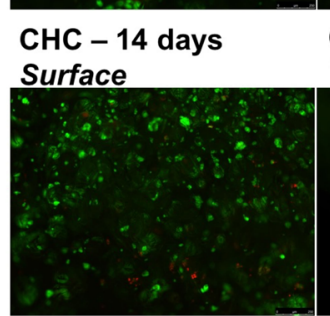

\section{PS (control) - 28 days}

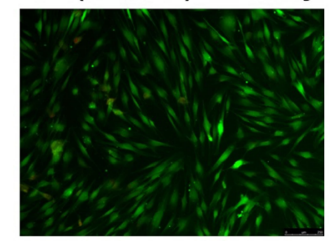

\section{CHC -28 days} Surface

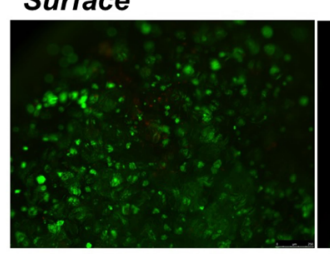

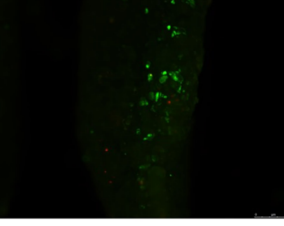

CHC -14 days Transversal

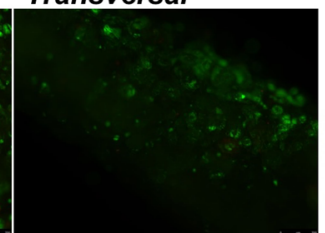

CHC -28 days Transversal

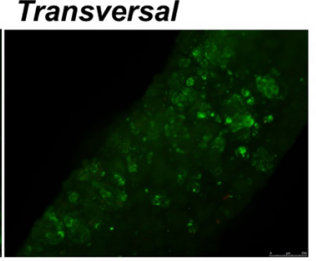

(E)

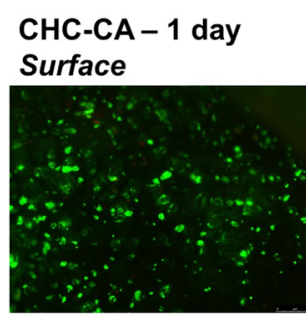

CHC-CA - 14 days Surface

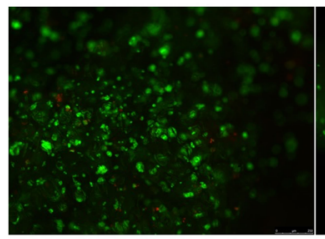

CHC-CA - 28 days Surface

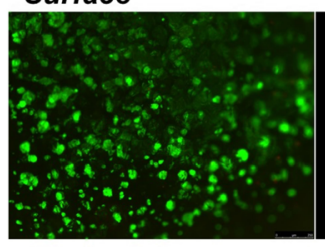

CHC-CA - 1 day Transversal

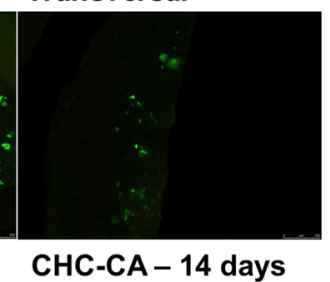

Transversal

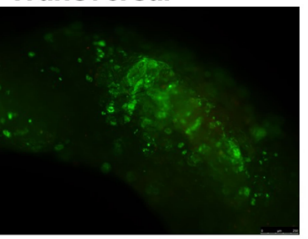

CHC-CA - 28 days Transversal
Fig. 5 Analysis of cell viability and proliferation. a Cell viability assay. Bars represent mean \pm standard deviation for percentages of live cells (live/dead assay) at each time point in the on PS (control), CHC, and CHC-CA groups $(n=4)$. No significant difference was observed among groups (two-way ANOVA; $p>0.05$ ). b Cell proliferation assay. Bars represent mean \pm standard deviation for percentage of cell metabolism at each time point $(n=6)$. Lower-case letters allow comparison between groups at each time point; upper-case letters allow comparison between time points for each group; different letters indicate significant differences (two-way ANOVA; Tukey's test; $p<0.05$ ). c, d, e Representative images of live/dead $(\times 20)$ assay of PS, CHC, and CHC-CA groups, respectively, at the material's surface, and inside the scaffolds structure (transversal slices), at the 1-, 14-, and 28-day time points pulp therapy, as the ideal product to be applied to pulp exposures should provide an optimal environment for complete healing of this specific connective tissue [3].

Regarding the bioactivity of the chitosan-collagen calcium-aluminate formulation, it was already demonstrated that the 2D architecture increased in around of 26.4, 57.2, and $400 \%$ the ALP activity, total protein expression, and
Fig. 6 SEM/EDS analysis of cell/materials constructs at 1-, 14-, and 28-day time points. a PS group, several cells covering the PS surface were observed at all time points. b, $\mathbf{c} \mathrm{CHC}$ and $\mathrm{CHC}-\mathrm{CA}$ groups, respectively; the cells were found covering the materials surface at all time points. The transversal slices at 28 days demonstrated the presence of cells inside the materials structure (arrows) when compared to the scaffolds with no cells. EDS analysis demonstrates the composition of the materials surface in contact with cells 


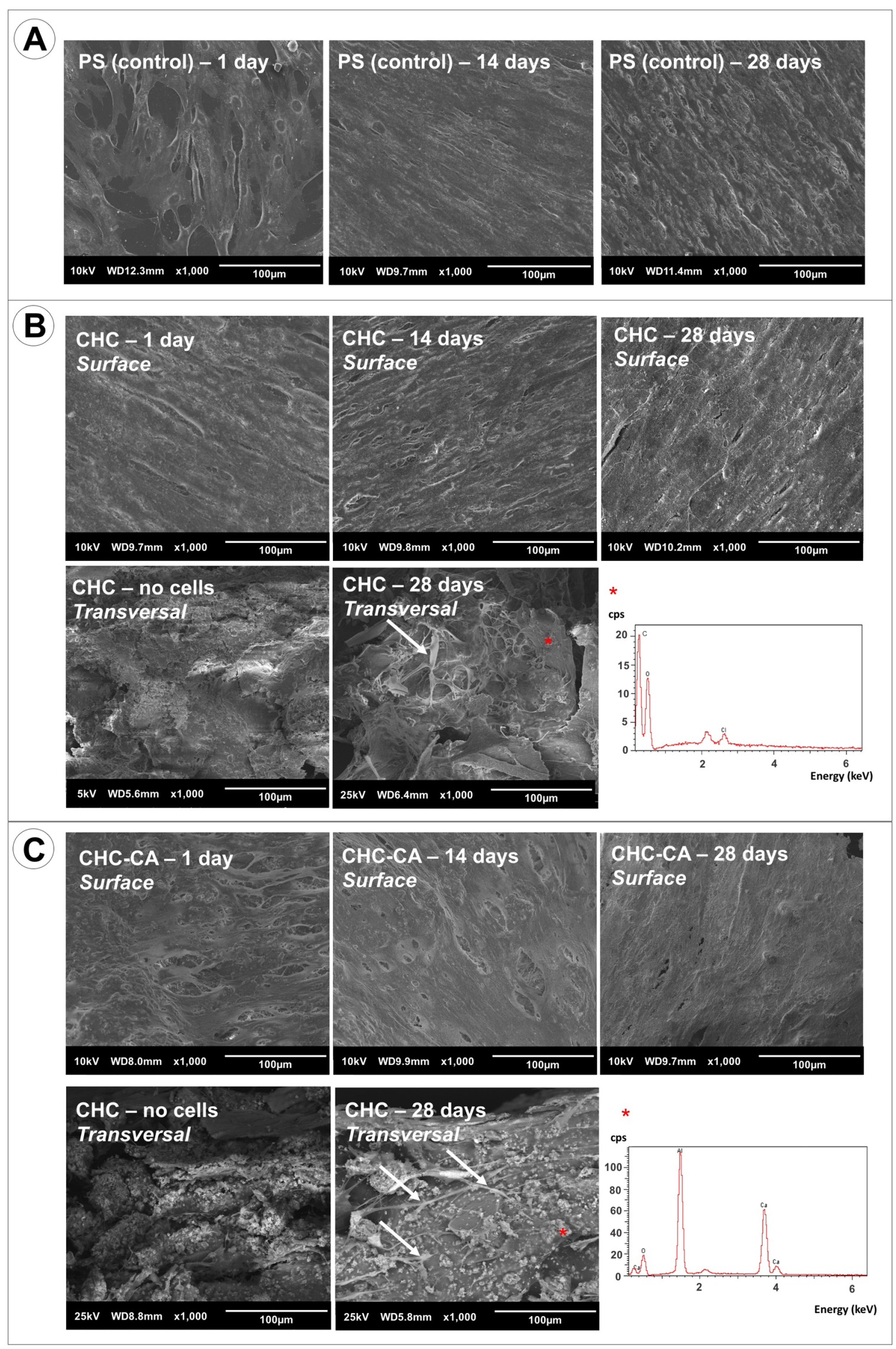


Fig. 7 Results of ALP activity (a), TP production (b), mRNA gene expression of DSPP (c) and DMP-1 (d), alizarin red staining (e), and micro-CT analysis (f). Lower-case letters allow comparison between groups at each time point; upper-case letters allow comparison between time points for each group; different letters indicate significant differences (one/twoway ANOVA; Tukey's test; $p<0.05)$. e Representative images of materials stained with alizarin red dye at the 28-day time point. Note the $\mathrm{CHC}$ and CHC-CA scaffolds with no cells stained with alizarin red for background subtraction (blank). $\mathbf{f}$ Representative images of 3D reconstruction of $\mathrm{CHC}$ and CHC-CA scaffolds before and after the 28 days of cell culture (transversal slices images). Note the intense amount of mineral structures (white dots) on CHC-CA scaffold at the 28-day period
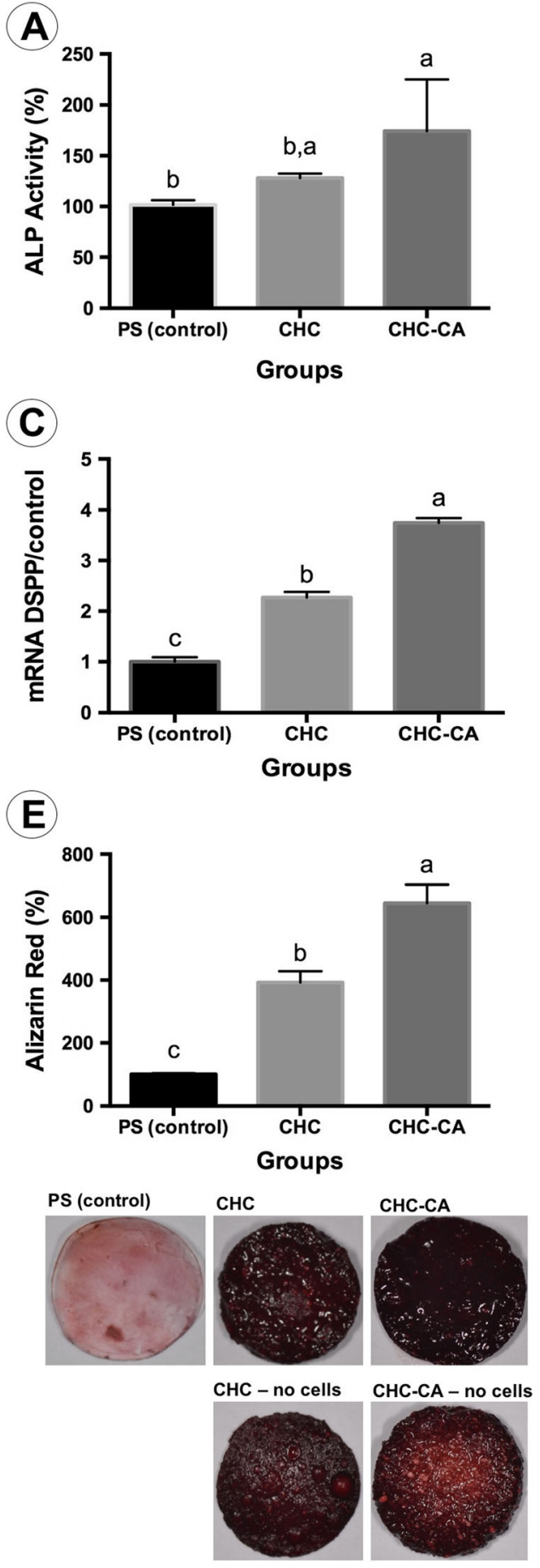

B

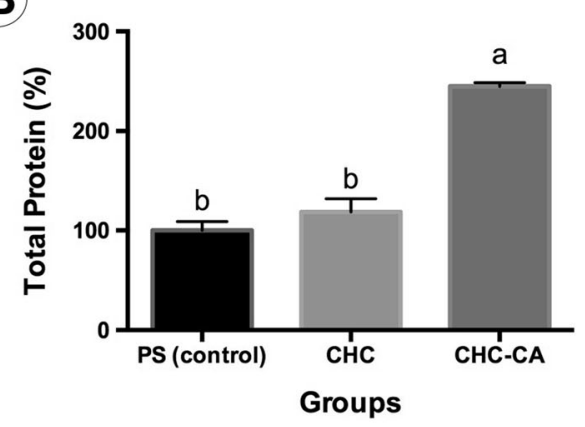

(D)

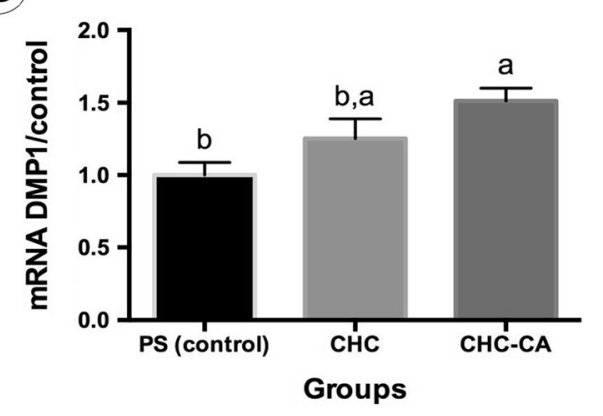

(F)
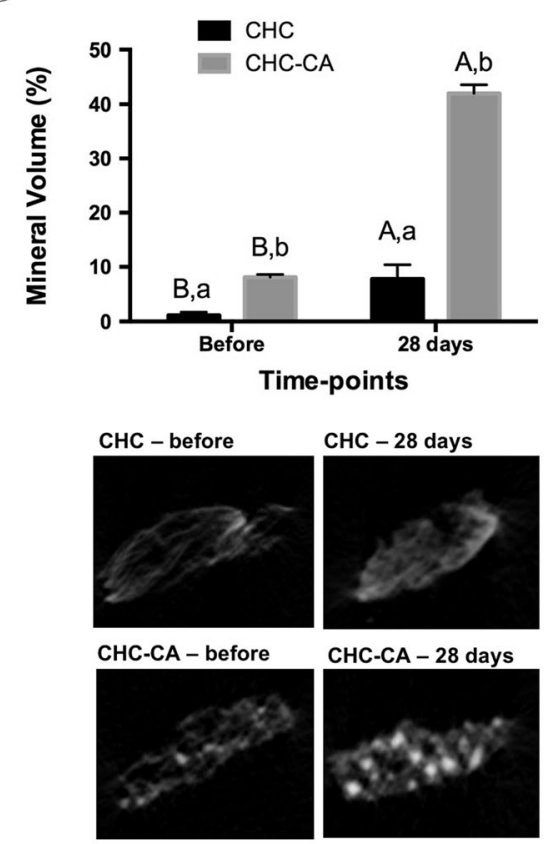

alizarin red staining, respectively, of HDPCs seeded onto its surface in comparison to those seeded on polystyrene (which represents $100 \%$ of cell parameters) [20]. In addition to these results, in the present investigation, the $3 \mathrm{D}$ architecture of CHC-CA scaffold allowed for increase in $74.2 \%$ of ALP activity, $126.3 \%$ in total protein expression, and $500 \%$ in mineralized matrix deposition (alizarin red assay) in comparison to PS group. Nevertheless, increase in DSPP and DMP-1 gene expression was observed for the CHC-CA scaffold, as was also observed for the 2D biomembrane [20]. Therefore, the 3D porous matrix of the CHC-CA allowed for a more intense expression of these secreted odontoblastic markers, culminating with the deposition of a great amount of calcium-rich matrix, demonstrating the potential for this biomaterial to act as a matrix-inducible, cell-mediated deposition and regulation of the mineral phase, a critical end-point hallmark feature for dentin regeneration. 
Similarly, Hu et al. [43] found that the 3D architecture (scaffold) played a significant role on MSC differentiation towards an osteogenic phenotype, leading to significantly higher amount of mineralized matrix deposition than that observed for a $2 \mathrm{D}$ matrix (flat film). According to the authors, the porous architecture of the scaffold results in more efficient cell proliferation and recapitulates the in vivo cues of extracellular matrix, which also possess a 3D environment. The porous matrix of the scaffolds allows for cell migration inside its structure, with cells adhering to the pore wall. In this scenario, the cells feature a $3 \mathrm{D}$ conformation of its cytoskeleton, whereas cells adhering to flat surfaces exhibit an elongated shape. According to $\mathrm{Hu}$ et al. [43], the 3D cell morphology has a differential effect on cell differentiation and new tissue deposition, resulting in higher deposition of mineralized matrix in the scaffold structure in comparison to flat surfaces. In the present investigation, the live/dead assay clearly demonstrates the migration of live cells inside the porous structure of the $\mathrm{CHC}$ and $\mathrm{CHC}-\mathrm{CA}$ scaffolds, with cells featuring a round shape in comparison to elongated shape of cells in PS group.

Amir et al. [21] demonstrated that chitosan has a bioactive potential, being capable of increasing cell proliferation, ALP activity, and mineralized matrix deposition on dental pulp stem cells in vitro. In a recent study, a biomembrane of chitosan induced the reparative dentinogenesis process when applied to the exposed pulp tissue on canine teeth. The thickness of mineralized barrier was similar to those observed when calcium hydroxide was used; however, no tissue necrosis was observed when chitosan was applied [23]. The addition of a mineral phase to chitosan/collagen scaffolds seems to increase the bioactivity of these biomaterials [44]. Pulp cells in contact with Ca-releasing cements are intensely induced to an odontoblastic phenotype in vitro $[45,46]$. Also, the results of in vitro and in vivo studies have shown that chitosan/collagen scaffolds containing a Ca-based mineral phase had superior ability for osteoblast phenotype induction and bone reconstruction [11-19]. The inclusion of a mineral phase provides an environment with chemical composition similar to that of the inorganic components of bone, increasing the osteoblastic phenotype. In addition, these composites feature enhanced mechanical property via matrix reinforcement $[9,44]$.

The results of the present investigation also demonstrated that the calcium-aluminate phase played a significant role on the regenerative potential of HDPCs, since the cells seeded on the CHC-CA scaffold featured higher expression of odontoblastic markers and mineralized matrix deposition than $\mathrm{CHC}$ scaffold. The $\mu \mathrm{CT}$ analysis confirms the presence of mineral matrix deposited by the cells after 28 days of cell culture, with minerals well distributed throughout the 3D structure of CHCCA scaffold. It was previously reported that calcium-aluminate cement is capable of inducing the expression of osteoblastic markers and mineralized matrix deposition when preosteoblasts were seeded onto its surface $[26,39]$. Also, an in vivo study conducted in rat molars demonstrated that calcium-aluminate cement enhanced dentin bridge deposition after its application to mechanically exposed pulps [47]. Soares et al. [20] observed that a chitosan-collagen calcium-aluminate biomembrane increased the dentinogenic potential of human dental pulp cells in vitro, leading to intense mineralized matrix deposition. Therefore, one may conclude that the intense mineralized matrix deposited by HDPCs seeded onto the CHC-CA surface observed in the present investigation can be attributed to the combined bioactive effects of chitosan-collagen organic matrix and the calcium-aluminate microparticles. Therefore, the chitosan-collagen calcium-aluminate porous matrix seems to present potential for pulp capping due to its chemotactic, cytocompatible, and bioactive characteristics, as demonstrated in the present in vitro investigation. However, further studies are needed to assess the mechanical characteristics of this composite, as well as its behavior when used in animal models.

\section{Conclusions}

The experimental scaffold composed of a porous chitosancollagen matrix embedded with calcium-aluminate microparticles induced human dental pulp cell migration, adhesion, and proliferation on its surface, followed by intense expression of odontoblastic phenotype markers and culminating in the deposition of high amounts of mineralized matrix. Therefore, this biomaterial seems to be an interesting candidate for in vivo application as a cell-free approach to dentin tissue engineering.

Acknowledgements The authors acknowledge the São Paulo Research Foundation -FAPESP (grants \# 2013/23520-0 and 2014/13034-3) - and the National Council for Scientific and Technological DevelopmentCNPq (grants \# 303599/2014-6 and 442336/2014-4).

\section{Compliance with ethical standards}

Conflict of interest The authors declare that they have no conflicts of interest.

Funding The work was supported by the São Paulo Research Foundation-FAPESP (grants \# 2013/23520-0 and 2014/13034-3) and the National Council for Scientific and Technological Development — CNPq (grants \# 303599/2014-6 and 442336/2014-4).

Ethical approval This study was approved by the Research Ethics Committee of the Araraquara Dental School/UNESP, São Paulo, Brazil (Proc. No 30939314.5.0000.5416). All procedures performed in studies involving human participants were in accordance with the ethical standards of the institutional and/or national research committee and with the 1964 Helsinki declaration and its later amendments or comparable ethical standards. 
Informed consent Informed consent was obtained from all individual participants included in the study.

\section{References}

1. Albuquerque MT, Valera MC, Nakashima M, Nör JE, Bottino MC (2014) Tissue-engineering-based strategies for regenerative endodontics. J Dent Res 93:1222-1231

2. Galler KM, Eidt A, Schmalz G (2014) Cell-free approaches for dental pulp tissue engineering. J Endod 40:S41-S45

3. Sangwan P, Sangwan A, Duhan J, Rohilla A (2013) Tertiary dentinogenesis with calcium hydroxide: a review of proposed mechanisms. Int Endod J 46:3-19

4. Schmalz G, Smith AJ (2014) Pulp development, repair, and regeneration: challenges of the transition from traditional dentistry to biologically based therapies. J Endod 40:S2-S5

5. Steindorff MM, Lehl H, Winkel A, Stiesch M (2014) Innovative approaches to regenerate teeth by tissue engineering. Arch Oral Biol 59:158-166

6. Morad G, Kheiri L, Khojasteh A (2013) Dental pulp stem cells for in vivo bone regeneration: a systematic review of literature. Arch Oral Biol 58:1818-1827

7. Gładysz D, Hozyasz KK (2015) Stem cell regenerative therapy in alveolar cleft reconstruction. Arch Oral Biol 60:1517-1532

8. Volponi AA, Sharpe PT (2013) The tooth: a treasure chest of stem cells. Br Dent J 215:353-358

9. Dard M, Sewing A, Meyer J, Verrier S, Roessler S, Scharnweber D (2000) Tools for tissue engineering of mineralized oral structures. Clin Oral Investig 4:126-129

10. Gupte MJ, Ma PX (2012) Nanofibrous scaffolds for dental and craniofacial applications. J Dent Res 91:227-234

11. Murphy WL, Simmons CA, Kaigler D, Mooney DJ (2004) Bone regeneration via a mineral substrate and induced angiogenesis. $\mathrm{J}$ Dent Res 83:204-210

12. $\mathrm{Xu} \mathrm{HH}$, Simon CG Jr (2005) Fast setting calcium phosphatechitosan scaffold: mechanical properties and biocompatibility. Biomaterials 26:1337-1348

13. Wang J, de Boer J, de Groot K (2008) Proliferation and differentiation of MC3T3-E1 cells on calcium phosphate/chitosan coatings. J Dent Res 87:650-654

14. Chicatun F, Pedraza CE, Ghezzi CE, Marelli B, Kaartinen MT, McKee MD, Nazhat SN (2011) Osteoid-mimicking dense collagen/chitosan hybrid gels. Biomacromolecules 12:2946-2956

15. Venkatesan J, Pallela R, Bhatnagar I, Kim SK (2012) Chitosanamylopectin/hydroxyapatite and chitosan-chondroitin sulphate/ hydroxyapatite composite scaffolds for bone tissue engineering. Int J Biol Macromol 51:1033-1042

16. Liu H, Peng H, Wu Y, Zhang C, Cai Y, Xu G, Li Q, Chen X, Ji J, Zhang Y, OuYang HW (2013) The promotion of bone regeneration by nanofibrous hydroxyapatite/chitosan scaffolds by effects on integrin-BMP/Smad signaling pathway in BMSCs. Biomaterials 34:4404-4417

17. Qiao P, Wang J, Xie Q, Li F, Dong L, Xu T (2013) Injectable calcium phosphate-alginate-chitosan microencapsulated MC3T3E1 cell paste for bone tissue engineering in vivo. Mater Sci Eng C Mater Biol Appl 33:4633-4639

18. Shen S, Fu D, Xu F, Long T, Hong F, Wang J (2013) The design and features of apatite-coated chitosan microspheres as injectable scaffold for bone tissue engineering. Biomed Mater 8:025007

19. Su WT, Wu PS, Ko CS, Huang TY (2014) Osteogenic differentiation and mineralization of human exfoliated deciduous teeth stem cells on modified chitosan scaffold. Mater Sci Eng C Mater Biol Appl 41:152-160
20. Soares DG, Rosseto HL, Basso FG, Scheffel DS, Hebling J, Costa CA (2016) Chitosan-collagen biomembrane embedded with calcium-aluminate enhances dentinogenic potential of pulp cells. Braz Oral Res 30:e54

21. Amir LR, Suniarti DF, Utami S, Abbas B (2014) Chitosan as a potential osteogenic factor compared with dexamethasone in cultured macaque dental pulp stromal cells. Cell Tissue Res 358:407-415

22. Farea M, Husein A, Halim AS, Abdullah NA, Mokhtar KI, Lim CK, Berahim Z, Mokhtar K (2014) Synergistic effects of chitosan scaffold and TGF $\beta 1$ on the proliferation and osteogenic differentiation of dental pulp stem cells derived from human exfoliated deciduous teeth. Arch Oral Biol 59:1400-1411

23. Li F, Liu X, Zhao S, Wu H, Xu HH (2014) Porous chitosan bilayer membrane containing TGF- $\beta 1$ loaded microspheres for pulp capping and reparative dentin formation in a dog model. Dent Mater 30:172-181

24. Tarsi R, Muzzarelli RA, Guzmán CA, Pruzzo C (1997) Inhibition of Streptococcus mutans adsorption to hydroxyapatite by lowmolecular-weight chitosans. J Dent Res 76:665-672

25. Bae K, Jun EJ, Lee SM, Paik DI, Kim JB (2006) Effect of watersoluble reduced chitosan on Streptococcus mutans, plaque regrowth and biofilm vitality. Clin Oral Investig 10:102-107

26. Castro-Raucci LM, Oliveira IR, Teixeira LN, Rosa AL, Oliveira PT, Jacobovitz M (2011) Effects of a novel calcium aluminate cement on the early events of the progression of osteogenic cell cultures. Braz Dent J 22:99-104

27. Aguilar FG, Roberti Garcia LF, Panzeri Pires-de-Souza FC (2012) Biocompatibility of new calcium aluminate cement (EndoBinder). J Endod 40:2024-2029

28. Okabe T, Sakamoto M, Takeuchi H, Matsushima K (2006) Effects of $\mathrm{pH}$ on mineralization ability of human dental pulp cells. J Endod 32:198-201

29. Tada H, Nemoto E, Kanaya S, Hamaji N, Sato H, Shimauchi H (2010) Elevated extracellular calcium increases expression of bone morphogenetic protein-2 gene via a calcium channel and ERK pathway in human dental pulp cells. Biochem Biophys Res Commun 394:1093-1097

30. Soares DG, Basso FG, Hebling J, de Souza Costa CA (2015) Immediate and late analysis of dental pulp stem cells viability after indirect exposition to alternative in-office bleaching strategies. Clin Oral Investig 19:1013-1020

31. Soleimani M, Nadri S (2009) A protocol for isolation and culture of mesenchymal stem cells from mouse bone marrow. Nat Protoc 4(1): 102-106

32. Gronthos S, Arthur A, Bartold PM, Shi S (2011) A method to isolate and culture expand human dental pulp stem cells. Methods Mol Biol 698:107-121

33. Soares DG, Ribeiro AP, da Silveira VF, Hebling J, de Souza Costa CA (2013) Efficacy and cytotoxicity of a bleaching gel after short application times on dental enamel. Clin Oral Investig 17:1901-1909

34. Piva E, Silva AF, Nör JE (2014) Functionalized scaffolds to control dental pulp stem cell fate. J Endod 40:S33-S40

35. Coyac BR, Chicatun F, Hoac B, Nelea V, Chaussain C, Nazhat SN, McKee MD (2013) Mineralization of dense collagen hydrogel scaffolds by human pulp cells. J Dent Res 92:648-654

36. Taravel MN, Domard A (1993) Relation between the physicochemical characteristics of collagen and its interactions with chitosan: I. Biomaterials 14:930-938

37. Howard C, Murray PE, Namerow KN (2010) Dental pulp stem cell migration. J Endod 36:1963-1966

38. Pires-de-Souza Fde C, Moraes PC, Garcia Lda F, Aguilar FG, Watanabe E (2013) Evaluation of $\mathrm{pH}$, calcium ion release and antimicrobial activity of a new calcium aluminate cement. Braz Oral Res 2013(27):324-330 
39. Silva EJ, Herrera DR, Rosa TP, Duque TM, Jacinto RC, Gomes BP, Zaia AA (2014) Evaluation of cytotoxicity, antimicrobial activity and physicochemical properties of a calcium aluminate-based endodontic material. J Appl Oral Sci 22:61-67

40. Adams GB, Chabner KT, Alley IR, Olson DP, Szczepiorkowski ZM, Poznansky MC, Kos CH, Pollak MR, Brown EM, Scadden DT (2006) Stem cell engraftment at the endosteal niche is specified by the calcium-sensing receptor. Nature 439:599-603

41. Yamaguchi T, Chattopadhyay N, Kifor O, Butters RR Jr, Sugimoto T, Brown EM (1998) Mouse osteoblastic cell line (MC3T3-E1) expresses extracellular calcium $\left(\mathrm{Ca}^{2+}{ }_{\mathrm{o}}\right)$-sensing receptor and its agonists stimulate chemotaxis and proliferation of MC3T3-E1 cells. J Bone Miner Res 13:1530-1538

42. Lansdown $\mathrm{AB}$ (2002) Calcium: a potential central regulator in wound healing in the skin. Wound Repair Regen 10:271-285

43. Hu J, Smith LA, Feng K, Liu X, Sun H, Ma PX (2010) Response of human embryonic stem cell-derived mesenchymal stem cells to osteogenic factors and architectures of materials during in vitro osteogenesis. Tissue Eng Part A 16:3507-3514

44. Kim IY, Seo SJ, Moon HS, Yoo MK, Park IY, Kim BC, Cho CS (2008) Chitosan and its derivatives for tissue engineering applications. Biotechnol Adv 26:1-21

45. Gandolfi MG, Spagnuolo G, Siboni F, Procino A, Rivieccio V, Pelliccioni GA, Prati C, Rengo S (2015) Calcium silicate/calcium phosphate biphasic cements for vital pulp therapy: chemicalphysical properties and human pulp cells response. Clin Oral Investig 19:2075-2089

46. Widbiller M, Lindner SR, Buchalla W, Eidt A, Hiller KA, Schmalz G, Galler KM (2016) Three-dimensional culture of dental pulp stem cells in direct contact to tricalcium silicate cements. Clin Oral Investig 20:237-246

47. Kramer PR, Woodmansey KF, White R, Primus CM, Opperman LA (2014) Capping a pulpotomy with calcium aluminosilicate cement: comparison to mineral trioxide aggregates. J Endod 40(9): 1429-1434 